\title{
EDITORIAL.
}

As we start Volume Six of our Journal, the most obvious change is that of the format. Our printers have now acquired the I.B.M. computorised equipment that spaces type autonatically, and enables us to run a two column page, with an increase of some $30 \%$ number of words on each page. The installation of the equipment, and the time spent in training the staff to operate it, have led to some inevitable delay in production, but the process of binding has been speeded up, and we hope the Journal will be distributed in a shorter time than previously after correction of the last proofs.

We still receive complaints from members that they are not receiving journals and notices, but careful investigation usually shows that mail has been despatched to the address the member gives us, but he fails to notify us properly of any subsequent changes of address. A new complete membership list shall be published during next year, so we would appreciate hearing from those who have changed name, or address, and from Affiliated Bodies whose address or official representative has been changed.

In the current issue of the Journal, we are delighted to welcome a group of Japanese orthopaedic surgeons to our contributors, and we also have two papers from America. With three clinical papers and three on exercise physiology, we hope to maintain a satisfactory balance between the two main interest groups of the B.A.S.M. We are doing our best to increase the quality and status of the Journal, which has already increased its circulation to libraries in many parts of the world, but lamentably not to enough post-graduate medical centres in this country. There does seem to be some awakening of interest in these centres into the topic of sports medicine, and we hope soon to be setting up lists of speakers on aspects of sports medicine, perhaps arranged on a regional basis. Not unexpectedly, a course of lectures is now in progress in the Slough region, a sports medicine symposium was held at Leicester by the College of General Practitioiners, and the P.G. Centre at Nottingham have held one meeting as part of their Autumn term of post-graduate training for general practitioners. We hope our members will do their best to spread the good word in their own areas, and encourage one-day meetings or regular courses, and also increase the circulation of the Journal (but please do not request back-numbers, which are now not available, with rare exceptions).

Since the publication of the last number of the Journal, the Annual General Meeting was held at Salford University, on June 26th. Secretary's and Treasurer's reports appear at the back of this issue. The Executive Committee had come to the end of their term of office, and elections took place. The offices of President - Sir Arthur Porritt; Chairman - Dr. G. G. Browning; and Treasurer/Editor - Dr. H. E. Robson, continued to be held by the previous occupants. A new office of ViceChairman was established, but the nominee for that office, Dr. Roger Bannister, felt obliged to withdraw his nomination on his appointment to be Chairman of the Sports Council, and the Executive Committee were asked to fill this vacancy. Dr. Peter Sperryn, formerly Conference Secretary to B.A.S.M. and Programme Secretary to the World Congress in Sports Medicine, has succeeded Dr. J. G. P. Williams as Hon. Secretary. Four members of the committee were elected;

Miss Suzan Livingston, Social Secretary at the World Congress.

Surg. Cdr. D. E. Mackay, R.N. formerly a co-opted member.

Dr. J. Moncur, - Hon. Sec. of the Scottish Area, B.A.S.M.

Dr. J. G. P. Williams.

Following the A.G.M., the new Executive Committee held a meeting to discuss future policy for the Association, and co-opted the following committee members:

Mr. H. Bertfield, F.R.C.S. - Orthopaedic Surgeon Lancashire.

Mr. H. Thomason, M.Sc., D.L.C. - University of Salford, and in charge of interpreters and translation facilities at the World Congress.

The introduction of new committee members leads inevitably to the loss of previous members, and the most grateful thanks of all members must be given to Surgeon Rear Admiral S. Miles R.N. (ret'd), Dr. R. Bannister, Mr. J. Kane, Ph.D., Dr. J. D. Troup, Dr. H. Burry and Mr. J. Buck, F.R.C.S. It would not be inappropriate at this time to pay a most sincere tribute to the work done by the former Hon. Secretary, John Williams. Ten years ago, he initiated the first B.A.S.M. meeting to be held outside London, and from that time, he threw himself whole-heartedly into the promotion of sports medicine in this country, as an administrative officer of B.A.S.M., as a dynamic member of the Institute of Sports Medicine, a prominent member of the U.N.E.S.C.O. International Sub-Committee on Doping in Sport, then as a member of the Committee of the International Federation of Sports Medicine (F.I.M.S.) and now as General Secretary of that organisation. The idea of holding the World Congress in Britain was John's idea, and his drive and enthusiasm caused this suggestion to be accepted by B.A.S.M. and F.I.M.S. He tackled the setting up of the congress and most of the detailed preparation virtually single-handed, and at only a small fraction of what similar congresses of F.I.M.S. have cost. His active participation in Sports Medicine and B.A.S.M. 
started when he was still a junior Registrar, and in the intervals of working for F.R.C.S. and Dip. Phys. Med. he wrote or was editor of three books. Our appreciation must also go to his wife Sally, who has had to establish a Sports Medicine office every time the family had to carry out the frequent moves junior hospital doctors seem to be making, and usually had a base functioning almost as soon as temporary cooking and sleeping facili- ties had been set up, not only for the family but also for the numerous guests who came to talk, sort papers, or argue, always sure of a kind reception, usually a meal and the offer of accommodation for the night. No one has done more than John to promote sports medicine in Britain, or to promote British sports medicine throughout the world.

\section{NOTE ADDED IN PROOF}

At a meeting of the Executive Committee held on November 4th 1971, the following were co-opted on to the Executive Committee.

Vice-Chairman:

Dr. B. Kiernander

Nominated by Affiliated Organisations:

British Olympic Association. Mr. K. S. Duncan.

C.C.P.R. Mr. H. Littlewood.

\section{LEADING ARTICLE FUTURE POLICY OF B.A.S.M.}

\section{Message from the Honorary Secretary}

For the last eighteen months the British Association of Sport and Medicine has produced the greatest event of its life to date - the World Congress of Sports Medicine and is subsequently getting to a stage of wondering "where next?" While in many respects the Congress was an outstanding success, from a domestic point of view it must be rated as either a failure or a non event because the percentage of our 600 home members helping with or attending the event was ridiculously small. While the Congress made a good impact in academic medical circles and has certainly raised the threshold of awareness of the existence of sports medicine in the medical profession, there is little sign that it has had a similar impact in the physical education and sports field. The Association has struggled for at least the last five years from one ad hoc meeting to the next, usually staged and presented by the same hard core of enthusiasts. The most noticable feature of our gradually increasing membership is its non-participation. The Executive Committee is therefore aware of the Association's deficiencies and is contacting all its affiliated associations as a matter of urgency to ask what that section of the membership requires from us.

The example and activities of our Scottish Section serves as a fine example of what the Association can and should be doing and there seems to be no reason why the members South of the border should not be as involved and keen as their Northern brethren. As a positive step in this direction 1 am endeavouring to revise the Association's activities during the next year or two in such a way as to try and consolidate our present membership and to try and make it feel more ready to involve itself actively rather than passively in the Association's affairs. I hope that the effect of establishing local area groups and meetings will be more successful than the previous tendency to rely on our meetings as National ones which has always meant that most of the membership will find it difficult to attend. While the Executive Committee can go so far as to set up Regional groups, it falls to the individual members themselves to ensure the success of these activities.

Apart from inore Regional Meetings we are trying to hold joint meetings with other local bodies such as physical educationists, physiotherapists, and doctors so that we may both enlarge our fields of interest and hopefully gain the benefit of more new members.

To summarise, in the aftermath of the World Congress the Association finds itself in a static phase with diminished funds and a largely uninvolved membership. 1 hope in the next year or two to see the growth of keenly involved active Regional Groups.

$$
\begin{aligned}
& \text { P. N. Sperryn, } \\
& \text { Honorary Secretary. }
\end{aligned}
$$

